\title{
Problematika Penyandang Disabilitas Dalam Pemilu Studi Kasus Pemilu Legislatif Tahun 2014 di Jakarta
}

\author{
Nadya Kharima
}

\begin{abstract}
Abstrak
General election, as a locust for citizens, functions to practice their voting rights, including those people with different abilities. Although there have been policies covering the right of the later, until now, the election system still facing problems for fulfilling the right for people with disabilities. Based on report documents of two general elections, this article discusses several crucial challenges such as data on people with disabilities, accessibility to voting venue, lack of understanding of both field officer and persons with disabilities. Thus, these situations reflect a big agenda for the expected future elections in regard to in the fulfillment of persons with disabilities rights.
\end{abstract}

Keywords: Penyandang Disabilitas, Pemilu, Aksebilitas.

\section{Pendahuluan}

Pemilu adalah mekanisme pemerintahan yang demokratis, karena wewenang pemerintahan hanya diperoleh atas persetujuan dari warga negara yang memilihnya. Secara universal pemilihan umum adalah lembaga sekaligus praktik politik yang memungkinkan terbentuknya sebuah pemerintahan perwakilan (representative goverment) yang menurut Dahl, merupakan gambaran ideal dan maksimal bagi suatu pemerintahan demokrasi di zaman modern (Robert A Dahl, 1992).

Kenapa kita memilih demokrasi? Karena demokrasi, sebagaimana dikatakan Dahl, menghasilkan akibat-akibat yang diinginkan suatu masyarakat dan negara, yakni: (1) menghindari tirani; (2) Hak Asasi Manusia; (3) Kebebasan Umum; (4) Menentukan nasib sendiri; (5) otonomi moral; (6) perkembangan manusia; (7) menjaga kepentingan; (8) persamaan politik. Sedangkan pada negara-negara demokrasi modern menghasilkan (9) perdamaian dan (10) kemakmuran.

(Abdul Hakim, 1996) mengatakan Pemilu ditinjau dari perspektif Hak Asasi Manusia (HAM), Pemilu merupakan pelaksanaan hak dasar dan masa depan kehidupan bersama dalam suatu masyarakat. Selanjutnya, Michael Saward mengemukakan bahwa demokratisasi sebuah sistem memerlukan beberapa kondisi minimal seperti jaminan basic freedom (freedom of speech and expression, freedom of movement, freedom of association, rights to equal treatment under the law); citizenship and participation; administrative code; publicity and social rights"."Kebebasan Dasar (kebebasan berbicara dan berekspresi, kebebasan bergerak, kebebasan berserikat, hak atas perlakuan yang sama di bawah hukum), kewarganegaraan dan partisipasi; kode administrasi, publisitas dan hak sosial,".

Karena itu, pemilu merupakan wadah untuk menyampaikan ekspresi dan keinginan masyarakat dalam menentukan arah suatu negara yang diselenggarakan secara berkala sehingga dalam Pemilu, suara warga negara yang sudah memenuhi hak untuk memilih dihitung sama dimana setiap orang yang memenuhi persyaratan mendapatkan kesempatan untuk menyatakan pendapatnya secara langsung atau melalui perwakilan yang dipilih secara langsung. Karena hak ini tak tergantikan (nonderogable), partisipasi semua kalangan harus dilindungi tanpa kecuali.

Meskipun Pemilu merupakan momentum yang sangat penting, justru Pemilu masih sering 
memunculkan permasalahan bagi penyandang disabilitas. Karena penyandang disabilitas merupakan kelompok penyandang disabilitas yang paling membutuhkan sarana khusus agar mereka dapat memilih secara mandiri sehingga dapat memenuhi asas pemilu yaitu Langsung, Umum, Bebas dan Rahasia (LUBER). Sehingga hak politik penyandang disabilitas selama ini masih belum terpenuhi secara maksimal lewat penyediaan aksesibilitas dalam Pemilu bagi mereka.

Sikap adil pada proses pemilu yakni kesamaan hak dan kesetaraan pada satu orang, satu suara, satu TPS, dan satu momentum hari pelaksanaan pemilu. Kondisi sedemikian ini akan memberikan pengaruh pada perubahan sikap masyarakat yang adil terhadap penyandang disabilitas diberbagai bidang kehidupan (Ariani, Konferensi Kesejahteraan Sosial, 20/8/13).

Padahal sudah jelas Payung hukum bagi disabilitas dalam Pemilu baik secara nasional maupun internasional, Undang-Undang (UU) Dasar 1945 setelah diamandemen Pasal 28H ayat 2: Setiap orang berhak mendapatkan kemudahan dan perlakuan khusus untuk memperoleh kesempatan dan manfaat yang sama guna mencapai persamaan dan keadilan. Dan Pasal 28I ayat 2: Setiap orang berhak bebas dari perlakuan yang bersifat diskriminatif atas dasar apapun dan berhak mendapatkan perlindungan terhadap perlakuan yang bersifat diskriminatif.

Kewajiban untuk memberikan akses pemilu di tingkat internasional pertama kali ditetapkan melalui deklarasi Universal Hak-hak Azazi Manusia pada tahun 1948 dan selanjutnya mengalami proses perkembangan dari tahun ke tahun. Pada saat ini, Konvensi Hak-hak Penyandang Disabilitas merupakan produk yang dengan jelas menyampaikan hak-hak azazi penyandang disabilitas.

Indonesia juga telah meratifikasi Kovenan Internasional Hak-Hak Sipil dan Hak Politik (International Covenant on Civil and Political Rights, ICCPR), yaitu perjanjian internasional yang dihasilkan Perserikatan Bangsa-Bangsa (PBB) tahun 1966. ICCPR mulai berlaku tahun 1976 dan telah diratifikasi oleh 141 negara. Substansi yang diatur dalam perjanjian ini adalah penghormatan atas hak asasi manusia yang mewajibkan kepada negara peserta untuk mentransformasikan ke dalam hukum nasional. Diantara isi ICCPR yang berkaitan dengan hak penyandang disabilitas adalah pasal 25 yang berbunyi "Setiap warga negara harus mempunyai hak dan kesempatan, tanpa pembedaan apapun untuk ikut serta dalam pelaksanaan urusan pemerintahan, baik secara langsung ataupun melalui wakil-wakil yang dipilih secara bebas; memilih dan dipilih pada pemilihan umum berkala yang murni, dan dengan hak pilih yang universal dan sama, serta dilakukan melalui pemungutan suara secara rahasia untuk menjamin kebebasan menyatakan keinginan dari para pemilih; dan memperoleh akses pada pelayanan umum di negaranya atas dasar persamaan dalam arti umum”.

Komisi Pemilihan Umum (KPU) sebagai penyelenggara pemilu juga telah membuat peraturan-peraturan yang terkait dengan penyandang disabilitas, seperti adanya kebijakan untuk alat bantu coblos (template braile) dimaksudkan agar pemilih disabilitas terutama yang netra dapat dengan mudah membaca nama calon anggota legislatif yang akan dipilih. Orientasi kebijakan yang dibuat KPU juga berorientasi kepada masalah (problem-oriented) dan tindakan (action-oriented) karena didalam peraturan serta buku panduan yang dibuat jelas diterapkan agar permasalahan yang dialami penyandang disabilitas dapat diatasi dengan tindakan-tindakan yang telah disesuaikan, seperti kebutuhan pendamping dalam TPS jika tidak ada dari pihak pemilih disabilitas maka petugas KPPS dapat menjadi pendamping. Berikut ini perbedaan kebijakan pemilu yang telah dibuat oleh KPU pada Tahun 2009 dengan Pemilu Tahun 2014: 
Tabel Perbedaan antara Kebijakan Pemilu Tahun 2009 dengan 2014

\begin{tabular}{|c|l|l|}
\hline No & \multicolumn{1}{|c|}{ Pemilu Tahun 2009 } & \multicolumn{1}{c|}{ Pemilu Tahun 2014 } \\
\hline 1 & $\begin{array}{l}\text { Buku Panduan/Bimbingan Tekhnis bagi } \\
\text { petugas PPK/PPS yang dibuat oleh KPU } \\
\text { tidak memuat informasi/materi tentang } \\
\text { pentingnya pemilu akses bagi penyan- } \\
\text { dang disabilitas. }\end{array}$ & $\begin{array}{l}\text { Buku Panduan KPPS telah memuat secara } \\
\text { lebih terperinci mengenai pemilu akses bagi } \\
\text { penyandang disabilitas, mulai dari pember- } \\
\text { itahuan adanya template braile bagi pemilih } \\
\text { disabilitas netra dan pengisian form C3 bagi } \\
\text { pendamping. }\end{array}$ \\
\hline 2 & $\begin{array}{l}\text { KPU tidak melibatkan organisasi/para } \\
\text { penyandang disabilitas dalam mendesain } \\
\text { dan merancang alat bantu bagi pemilih } \\
\text { penyandang disabilitas. }\end{array}$ & $\begin{array}{l}\text { KPU melibatkan organisasi penyandang dis- } \\
\text { abilitas atau PPUA Penca dalam kebijakann- } \\
\text { ya bahkan KPU meminta kepada penyandang } \\
\text { disabilitas netra untuk turun ke pabrik pem- } \\
\text { buatan template braile_untuk mengukur kete- } \\
\text { balan dari template braile untuk surat suara. }\end{array}$ \\
\hline 3 & $\begin{array}{l}\text { Penggunaan tanda contreng yang menyu- } \\
\text { litkan penyandang disabilitas netra karena } \\
\text { contreng dapat dipersepsi banyak hal. }\end{array}$ & $\begin{array}{l}\text { Penggunaan tanda coblos dianggap lebih } \\
\text { memudahkan penyandang disabilitas netra } \\
\text { karena dapat dilakukan sendiri tanpa bantuan } \\
\text { pendamping. }\end{array}$ \\
\hline
\end{tabular}

Namun ketika kebijakan-kebijakan yang telah lahir dalam pemilu dirasa cukup untuk menopang akses penyandang disabilitas dalam pemilu, kenyataannya adalah masih ada beberapa masalah yang masih menjadi kendala bagi penyandang disabilitas dalam memenuhi haknya di pemilu. Karenanya menjadi penting jika kita mencoba melihat problematika apa saja yang dihadapi penyandang disabilitas berdasarkan hasil yang didapatkan penulis ketika di lapangan pada saat pemungutan suara pemilu legislatif 2014 tengah berlangsung yaitu pada tanggal 9 April 2014 dan hasil beberapa laporan pemantauan akses pemilu legislatif 2014 oleh Jaringan pendidikan pemilih untuk rakyat (JPPR), PPUA Penca dan AGENDA. Berikut problematika yang dihadapi penyandang disabilitas dalam pemilu:

\section{Tidak ada data valid penyandang disabilitas yang memiliki hak suara dalam Pemilu 2014}

Permasalahan pertama yang terdapat dalam Pemilu 2014 adalah jumlah penyandang disabilitas yang memiliki hak suara. Untuk mengetahui berapa jumlah penyandang disabilitas di Indonesia saja kita kesulitan untuk mendapatkannya. Salah satu pertanyaan yang sering mengemuka terkait isu disabilitas dalam Pemilu adalah, apakah jumlah pemilih penyandang disabilitas itu banyak di Indonesia, sehingga aksesibilitas bagi mereka perlu diperjuangkan? Banyak atau sedikitnya jumlah penyandang disabilitas bukanlah alasan untuk tidak memfasilitasi aksesibilitas dalam Pemilu.

KPU dituding tidak memiliki jumlah data pemilih penyandang cacat di Pemilu 2014. Data pemilih penderita disabilitas diyakini hilang sejak Pemilu 2009. Ketua Pusat Pemilihan Umum Akses Penyandang Cacat (PPUA Penca), Heppy Sebayang mengatakan data pemilih penyandang disabilitas di Pemilu 2014 hilang dan tidak muncul datanya di KPU begitupun di DP4 dari Kemendagri. Masalah hilangnya data ini pernah terjadi seperti di Pemilu 2009. Menurutnya, di Pemilu 2004 meski tidak begitu banyak data pemilih penyandang cacat di seluruh wilayah Indonesia tetapi terdata di Daftar Pemilih Tetap (DPT) Pemilu 2004. Sayangnya sejak di Pemilu 2009 dan Pemilu 2014 data pemilih penyandang 
cacat seperti penderita tuna netra, tuna daksa, tuna rungu, penguna kursi roda, penguna tongkat dan cacat lain-lain, dihilangkan. Alasan hilangnya data itu tidak diketahuinya (Sabbarudin: 2014).

Berdasarkan data Pusat Data dan Informasi Kesejahteraan Sosial (Pusdatinkesos, 2012) terdapat 1.249.540 penyandang disabilitas yang tersebar di seluruh provinsi. Pada tahun 2011, Provinsi Jawa Tengah (18,91 persen), Jawa Timur (14,35 persen), Nusa Tenggara Barat (12,90 persen) dan Jawa Barat (10,43 persen) merupakan provinsi dengan jumlah penyandang disabilitas paling banyak di Indonesia. Hanya keempat provinsi tersebut yang jumlah penyandang disabilitasnya lebih dari 10 persen atau lebih dari 125 ribu orang.

Tabel Data Penyandang Disabilitas di Beberapa Kota besar di Indonesia pada Tahun 2011

\begin{tabular}{|c|l|l|l|}
\hline No & \multicolumn{1}{|c|}{ Provinsi } & \multicolumn{1}{c|}{ Jumlah } & \multicolumn{1}{c|}{ Presentase } \\
\hline 1 & DKI Jakarta & 8.495 & 0,68 \\
\hline 2 & Jawa Barat & 130.324 & 10,43 \\
\hline 3 & Jawa Tengah & 236.304 & 18,91 \\
\hline 4 & Banten & 20.712 & 1,66 \\
\hline 5 & Jawa Timur & 179.344 & 14,35 \\
\hline 6 & Yogyakarta & 30.887 & 2,47 \\
\hline 7 & Bali & 18.861 & 1,51 \\
\hline 8 & Nusa Tenggara Barat & 161.147 & 12,90 \\
\hline
\end{tabular}

Sumber: Pusdatinkesos Kemensos RI, 2012

Namun sayangnya dari jumlah tersebut, berapakah jumlah pemilih penyandang disabilitas? Sampai saat ini data pemilih penyandang disabilitas belum bisa diketahui secara pasti karena minimnya sumber informasi tentang itu. Bahkan penyelenggara pemilu yaitu Komisi Pemilihan Umum (KPU) dianggap tidak memiliki data pemilih penyandang disabilitas untuk Pemilu 2014, dimana hal ini pernah terjadi juga pada Pemilu 2009 yang lalu. Seperti Tabel yang tertera di bawah ini merupakan rekapitulasi DPT (Daftar Pemilih Tetap) yang dilakukan oleh KPU di wilayah Jakarta, nampak tidak terdapat keterangan jumlah penyandang disabilitas ke dalam DPT:

Tabel DPT per TPS yang disusun oleh KPU

\begin{tabular}{|c|c|c|c|c|c|c|c|c|}
\hline \multirow[b]{3}{*}{ Kabupaten/Kota } & \multicolumn{8}{|c|}{ Rekapitulasi DPT Sidalih } \\
\hline & \multirow[b]{2}{*}{$\begin{array}{l}\text { Jml. } \\
\text { TPS }\end{array}$} & \multicolumn{4}{|c|}{ Jumlah Pemilih } & \multirow{2}{*}{$\begin{array}{c}\text { Tgl } \\
\text { Lahir } \\
\text { Nihil } \\
(\%)\end{array}$} & \multirow{2}{*}{$\begin{array}{c}\text { Status } \\
\text { Kawin } \\
\text { Nihil } \\
(\%) \\
\end{array}$} & \multirow{2}{*}{$\begin{array}{c}\text { Belum } \\
\text { Kawin } \\
(\%)\end{array}$} \\
\hline & & $\mathbf{L}$ & $\mathbf{P}$ & $\begin{array}{c}\text { Nihil } \\
\text { (\%) }\end{array}$ & Total & & & \\
\hline 1. Jakarta Barat & 3.818 & 836.737 & 804.352 & 0 & 1.641 .089 & 0 & 0 & 0 \\
\hline 2. Jakarta Pusat & 1.852 & 386.372 & 376.620 & 0 & 762.992 & 0 & 0 & 0 \\
\hline 3. Jakarta Selatan & 3.769 & 789.719 & 772.927 & 0 & 1.562 .646 & 0 & 0 & 0 \\
\hline 4. Jakarta Timur & 4.675 & 965.988 & 951.016 & 0 & 1.917 .004 & 0 & 0 & 0 \\
\hline 5. Jakarta Utara & 2.877 & 567.484 & 550.958 & 0 & 1.118 .442 & 0 & 0 & 0 \\
\hline 6. Kepulauan Seribu & 54 & 11.020 & 8.321 & 0 & 19.341 & 0 & 0 & 0 \\
\hline TOTAL & 17.045 & 3.557.320 & 3.464 .194 & $\mathbf{0}$ & 7.021 .514 & $\mathbf{0}$ & $\mathbf{0}$ & $\mathbf{0}$ \\
\hline
\end{tabular}

Sumber: KPU, 2014 
Berdasarkan hasil pemantauan JPPR dikatakan bahwa semua Tempat Pemungutan Suara (TPS) yang dipantau oleh relawan JPPR di DKI Jakarta tidak ada satupun pencantuman Daftar Pemilih Tetap (DPT) yang menyebutkan keterangan jumlah penyandang disabilitas dan masih ditemukan TPS yang tidak memasang DPT di papan pengumuman untuk mempermudah informasi bagi penyandang disabilitas dan masyarakat.

Banyak penyandang disabilitas yang hingga saat ini tidak didaftarkan sebagai peserta pemilu karena berbagai alasan. Seperti, penyandang disabilitas yang dari daerah lain dan masih di rehabilitasi yang mengakibatkan mereka tidak bisa pulang ke daerahnya karena dengan pertimbangan berat biaya transport. Untuk Penyandang disabilitas di DKI saja jumlahnya 500-an hingga mencapai 1000 orang, sebagian besar masih tinggal di panti tersebut dan berhak untuk memilih. Saat ini katanya penduduk yang Potesial mencapai 3,6 juta jiwa dan ini pun belum termasuk masyarakat yang merasa dirinya cacat namun hingga saat ini belum dilakukan pendataan (Zak: 2013).

Hal ini sangat disayangkan, mengingatkan untuk menciptakan pemilu yang aksebilitas perlu adanya data yang tepat dan akurat terhadap berapa jumlah pemilih disabilitas. Karenanya menjadi penting bagi KPU untuk dapat memastikan berapa jumlah pemilih disabilitas serta memastikan bahwa di setiap TPS terdapat kepastian jumlah pemilih disabilitas sehingga petugas yang ada menjadi lebih respon terhadap aksebilitas di dalam TPS tersebut.

\section{Lokasi TPS yang belum aksebilitas bagi penyandang disabilitas}

Bukan hanya soal data, berdasarkan pengalaman Pemilu 2009, suara kaum marginal paling banyak diselewengkan. Penyebabnya, KPU tidak menyediakan kebutuhan yang mereka perlukan. Mulai dari Tempat Pemungutan Suara, alat bantu pencoblosan, kertas suara,hingga mereka yang diberi kepercayaan untuk mendampinginya (Gunawan: 2013). Dan memang kenyataannya adalah pada Pemilu 2014 ini masih terdapat lokasi TPS yang tidak aksesibel bagi penyandang disabilitas. Hal ini berdasarkan temuan dari JPPR, seperti sempitnya jarak bilik suara dengan tembok pembatas (susah untuk manuver), terlalu tingginya kotak pemungutan suara bagi penyandang tuna daksa, masih ada lokasi jalan menuju TPS yang menanjak dan terdapat tangga, dll.

Salah satunya contoh kasusnya adalah di TPS 026 Kampung Bali, Rt 05/ Rw 10 Kecamatan Tanah Abang, Jakarta Pusat, letaknya yang agak menanjak, jarak antar bilik yang sangat rapat sehingga menyulitkan untuk penyandang disabilitas untuk masuk kebilik suara. Di TPS 045 Kelurahan Sukabumi Selatan, Kec. Kebon Jeruk Jakarta juga memilki kondisi yang sama, lokasi TPS yang tidak akses karena menggunakan halaman rumah warga, bilik suara yang berdekatan dan antara jalur masuk dengan jalur keluar yang sama.

Temuan JPPR juga masih mendapatkan adanya TPS yang tidak aksesibel terhadap penyandang disabilitas Daksa, terlihat dari lokasi menuju TPS terdapat tangga yang harus dilewati, terlalu sempitnya jarak antara bilik suara dengan tembok pembatas sehingga pengguna kursi roda tidak bisa bergerak dengan leluasa dan terlalu tingginya kotak suara sehingga sulit untuk diakses oleh penyandang disabilitas Daksa.

Kemudian soal alat bantu coblos (template) braille khusus bagi penyandang disabilitas netra di TPS, hal ini menjadi penting karena template braille merupakan salah satu penunjang bagi penyandang disabilitas untuk memberikan suaranya yang ternyata hanya disediakan untuk tingkatan DPD saja, sedangkan untuk DPRDnya tidak ada. Padahal penyandang disabilitas mengaku bahwa 
sama pentingnya untuk disediakan template braile untuk DPRD mengingat banyaknya caleg yang harus diperhatikan. Selain itu, ketersediaan template braile yang tidak semua TPS memilikinya sehingga menyulitkan penyandang disabilitas yang ingin melakukan pencoblosan suara. Data yang diperoleh oleh PPUA Penca terhadap alat bantu coblos (template) di TPS berdasarkan Hasil Data Sementara: Survey PPUA Penca Pemilu 9 April (Update 29/04/2014):

\section{Grafik Alat Bantu Coblos (Template) di TPS}

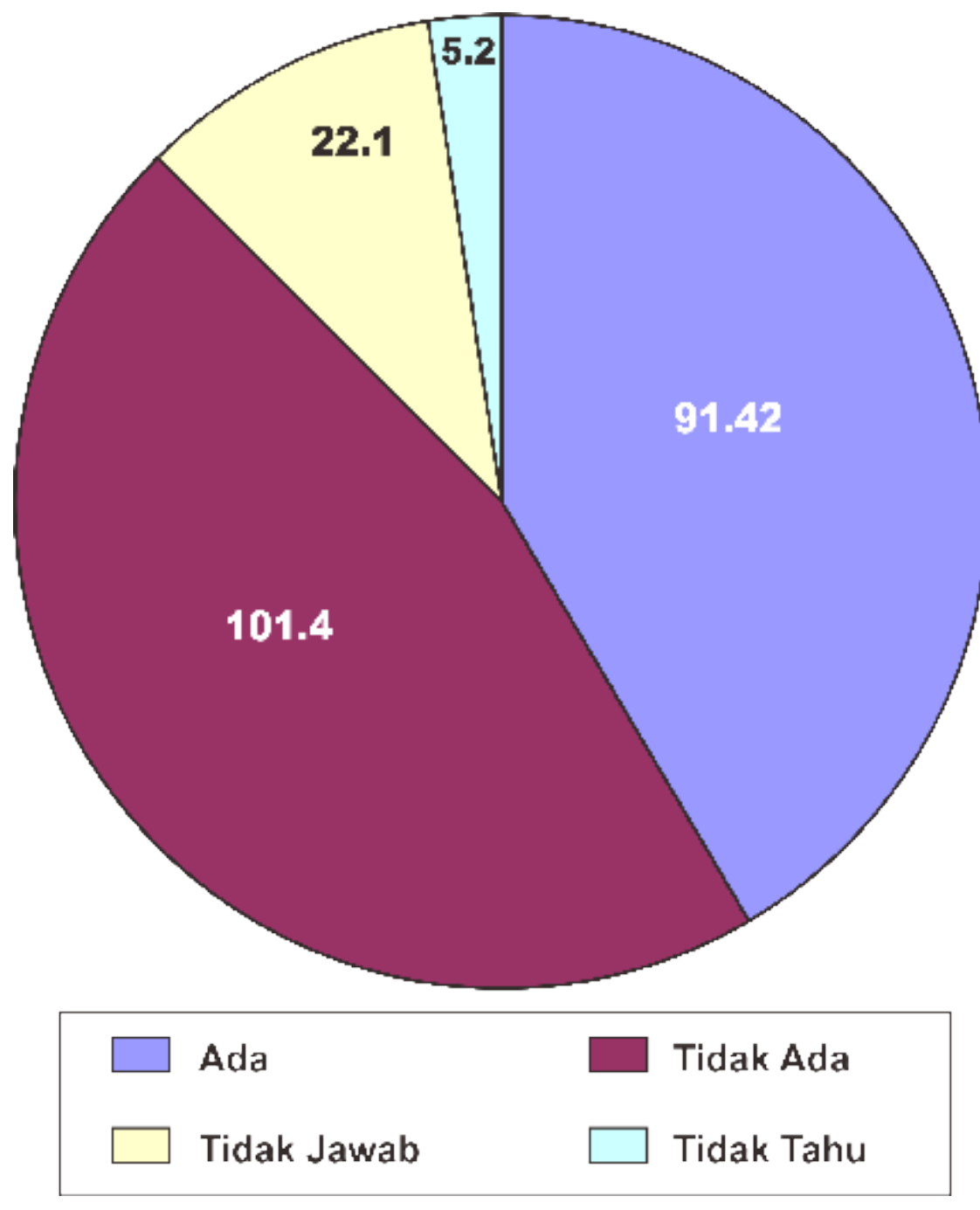

Sumber: PPUA Penca, 2014

Padahal di tahun 2013, General Election Network For Disability Access (AGENDA) telah memberikan pemantuannya bahwa TPS yang lokasinya mudah diakses dengan pemilih penyandang disabilitas dan yang secara fisik dirancang untuk membantu mereka mendapatkan masalah yang signifikan di Indonesia. Rata-rata, hanya di bawah setengah dari TPS (42\%) yang dikunjungi oleh para pemantau AGENDA tidak cocok untuk pemilih dengan gangguan mobilitas. Di Indonesia untuk lokasi TPS ada di lapangan, tempat terbuka, gedung sekolah, lokasi TPS tidak diberi banyak pertimbangan oleh KPUD dari awal. Karena ada sedikit pembatasan di Indonesia dibandingkan dengan negara-negara lain yang membatasi lokasi TPS ke sekolah-sekolah, KPU memiliki pilihan yang lebih banyak dan karena itu tidak seharusnya memiliki kesulitan mengidentifikasi lokasi yang 
dapat diakses dalam banyak kasus. Sehingga sudah seharusnya KPU lebih responsif dalam menangani persoalan aksebilitas ini.

\section{Pemahaman Kelompok Penyelenggaraan Pemungutan suara (KPPS) terhadap Pemilu yang aksebilitas.}

Tingkat pemahaman KPPS sangat kurang terutama dalam memahami kebijakan penyandang disabilitas dalam pemilu. Padahal KPPS merupakan salah satu ujung tombak terwujudnya aksebilitas yang baik dalam Pemilu karena pada saat penyandang disabilitas menyalurkan hak suaranya di TPS perlu adanya KPPS yang memahami bagaimana penyandang disabilitas tersebut mendapatkan akses pemilu yang baik sesuai dengan peraturan yang telah dibuat oleh KPU. Dari 3 (tiga) TPS yang dilakukan observasi oleh penulis, KPPS tidak melakukan sesuai dengan apa yang diterjemahkan kebijakan KPU melalui buku panduan KPPS yaitu:

a. KPPS tidak Menjelaskan tata cara pengunaan template braile dan pengisian form C3.

b. 2 TPS yaitu TPS 14 Kampung Rawa dan 95 Duri Kelapa, petugas KPPSnya baru memberikan template braile dan ketika diminta oleh penyandang disabilitas.

c. KPPS tidak menuliskan keterangan penyandang disabilitas di form C6.

Para penyandang Disabilitas serta pendamping juga merasa bahwa anggota KPPS tidak memiliki pemahaman yang cukup mengenai aturan yang telah ditetapkan KPU untuk penyandang disabilitas. Sehingga banyak terjadi kekurangan, terutama terkait persoalan template dan form C3 yang tidak disampaikan dan di dua TPS KPPS memberikan ketika diminta saja oleh pemilih disabilitas, seperti yang dikatakan ES, salah satu penyandang disabilitas netra saat melakukan pencoblosan:

"Ketika kita datang itu, si ketua KPPS itu tidak mengarahkan kepada pendamping, itu karena saya tahu jadi saya meminta form C3 untuk pendamping, jadi dia tidak siap untuk itu. Yang kedua, dari tempat layoutnya TPS itu tidak sesuai untuk disabilitas karena ada legokan yang menyulitkan disabilitas, ". (ES, 9 April 2014)

Berdasarkan pemantauan JPPR juga ditemukan beberapa kendala yang masih dihadapi oleh Pemilih disabilitas netra yang permasalahannya terdapat di KPPS yang tidak memahami tugasnya terhadap pemilih disabilitas dimana petugas KPPS masih banyak yang belum memahamai panduan teknis kebutuhan dan pentingnya pemilu akses bagi penyandang disabilitas, berikut temuannya:

Temuan JPPR terhadap Kendala Pemilih Disabilitas di Jakarta pada Pemilu Legislatif 2014

\begin{tabular}{|c|c|c|c|}
\hline No & Disabilitas & $\begin{array}{l}\text { Jumlah } \\
\text { Pemilih }\end{array}$ & Kendala yang Masih Dihadapi \\
\hline 1 & Tuna Netra & 13 & $\begin{aligned} & \text { Petugas KPPS tidak menawarkan kepada pendamping pen- } \\
& \text { yandang tuna netra untuk menandatangani Formulir C3. } \\
&>\text { Petugas KPPS kurang memahami hal-hal teknis pemilu } \\
& \text { akses bagi penyandang tuna netra (braille template) yang } \\
& \text { dijauhakn dari lokasi tempat pemungutan kertas suara. } \\
&>\text { Masih dijumpai panitia yang tidak memberikan tawaran } \\
& \text { bantuan kepada pemilih tuna netra, dan ditemukan adanya }\end{aligned}$ \\
\hline
\end{tabular}




\begin{tabular}{|c|c|c|c|c|}
\hline & & & & $\begin{array}{l}\text { kesulitan untuk pencoblosan ketika berada di bilik suara } \\
\text { Ada pemilih tuna netra yang hanya diberi surat suara DPD } \\
\text { karena dianggap hanya milih DPD yang mempunyai tem- } \\
\text { plate braille. }\end{array}$ \\
\hline \multirow[t]{2}{*}{2} & Tuna Daksa & 44 & & $\begin{array}{l}\text { Masih dijumpai adanya Petugas KPPS yang tidak men- } \\
\text { awarkan bantuan kepada pemilih Tuna Daksa pada saat } \\
\text { akan melakukan pemungutan suara. } \\
\text { Masih ditemukan lokasi TPS yang tidak aksesible (kesuli- } \\
\text { tan menjangkau bilik suara, memasukkan kertas suara) bagi } \\
\text { penyandang Tuna Daksa yang tidak memilki pendamping. }\end{array}$ \\
\hline & & & & $\begin{array}{l}\text { Masih ditemukan lokasi TPS yang tidak aksesible (kesuli- } \\
\text { tan menjangkau bilik suara, memasukkan kertas suara) bagi } \\
\text { penyandang Tuna Daksa yang tidak memilki pendamping. } \\
\text { Masih ditemukan beberapa pendamping Tuna Daksa yang } \\
\text { tidak menandatangani Formulir C3, dan Petugas KPPS ti- } \\
\text { dak menyodorkan Formulir C3 untuk ditandatangani. }\end{array}$ \\
\hline 3 & Tuna Rungu & 5 & & $\begin{array}{l}\text { Petugas KPPS tidak menawarkan bantuan pendamping ke- } \\
\text { pada penyandang Tuna Rungu. } \\
\text { Masih ditemukan adanya Petugas KPPS yang tidak mem- } \\
\text { berikan Petunjuk Non-verbal, memberikan tanda khusus } \\
\text { dan memberikan informasi tentang tata cara pemungutan } \\
\text { suara kepada penyandang Tuna Rungu. } \\
\text { Pendamipng Tuna Rungu tidak menandatangani Formulir } \\
\text { C3 dan Petugas KPPS tidak memberikan Formulir C3. }\end{array}$ \\
\hline 4 & Tuna Grahita & 7 & & $\begin{array}{l}\text { Petugas KPPS tidak menawarkan bantuan pendamping ke- } \\
\text { pada penyandang Tuna Grahihta. }\end{array}$ \\
\hline
\end{tabular}

Belum lagi persoalan kerahasiaan pilihan politik penyandang disabilitas masih belum terjaga sepenuhnya, karena dengan ditemukannya petugas KPPS yang membentuk melipat kertas suara diluar bilik tempat pemungutan suara sehingga terlihat jelas bahwa pemahaman KPPS juga masih dianggap kurang memahami dalam aksbilitas dalam penyandang disabilitas.

Tidak hanya pengetahuan dan pemahaman KPPS saja, dalam hal kemampuan menyampaikan kebijakan yang telah dibuat oleh KPU untuk dimplementasikan juga kurang, padahal kemampuan menyampaikan ini menjadi salah satu faktor penting bagi KPPS agar pemungutan suara yang dilaksanakan dapat tetap aksesbel. Seperti yang disampaikan oleh Koordinator Nasional JPPR, Masyukurudin Hafidz:

"Maksudnya gini layout TPS bisa tidak akses, alat bantu untuk DPR tidak ada, tetapi kunci utamanya adalah di aspek pelayanan orang, kalau orang petugas TPS nya punya aspek disabilitas, betul betul melayani, semangat menjaga kerahasiaan, tuna netra misalnya datang ke TPS, "pak selamat datang, saya masykur KPPS disini, kalau mau menemani tidak langsung ditarik, saat memberikan suara betul-betul merahasiakan dan mengisi form pendamping, jadi kalau petugasnya punya aspek pelayanan yang kuat itu sebetulnya bisa,". 


\section{Pemahaman penyandang disabilitas terhadap aksesibilitas dalam Pemilu}

Dari temuan di lapangan, masih banyak penyandang disabilitas yang tidak memahami pentingnya aksebilitas bagi dirinya dalam menyalurkan hak suara politik di dalam Pemilu 2014. Misalnya saja di salah satu TPS masih ditemukan adanya penyandang disabilitas netra yang tidak menanyakan template braile dan tidak menggunakan pendamping sehingga mengalami kesulitan ketika mencoblos, melipat suara hingga memasukkan surat suara.

Hambatan dari faktor kelompok sasaran inilah dimana sebagai user harusnya dapat lebih aktif dalam memperjuangkan hak-haknya sehingga dapat memunculkan sinergi kedua belah pihak terutama di level terendah atau ketika proses implementasi di lapangan. seperti yang dikemukan Komisioner Badan Pengawas Pemilu (Bawaslu), Nasrullah:

"Penyandang disabilitas lebih banyak menyuarakan tuntutan-tuntutannya didalam pemenuhan haknya dalam regulasi KPU maupun Bawaslu, agar betul-betul sinergi, tidak hanya berhenti di wilayah KPU dan Bawaslu, tetapi juga Undang-undang. Ada semacam advokasi yang kuat dan kental dan memberikan advokasi kepada penyandang disabilitas yang tidak dapat diberikan haknya,".

Lembaga Survey Indonesia (LSI) dan International Foundation for Electoral Systems (IFES) melakukan jajak pendapat terhadap 1890 responden yang mewakili para pemilih di Indonesia (17 tahun keatas atau sudah menikah) di semua provinsi (33 provinsi) di Indonesia pada tanggal 17 sampai 30 Desember 2013. Dalam survey menyebutkan bahwa 67\% responden mengatakan bahwa penting melibatkan penyandang disabilitas dalam kegiatan Pemilu, seperti pada tabel berikut:

\section{Grafik Pentingnya Melibatkan Penyandang Disabilitas dalam Kegiatan Pemilu}

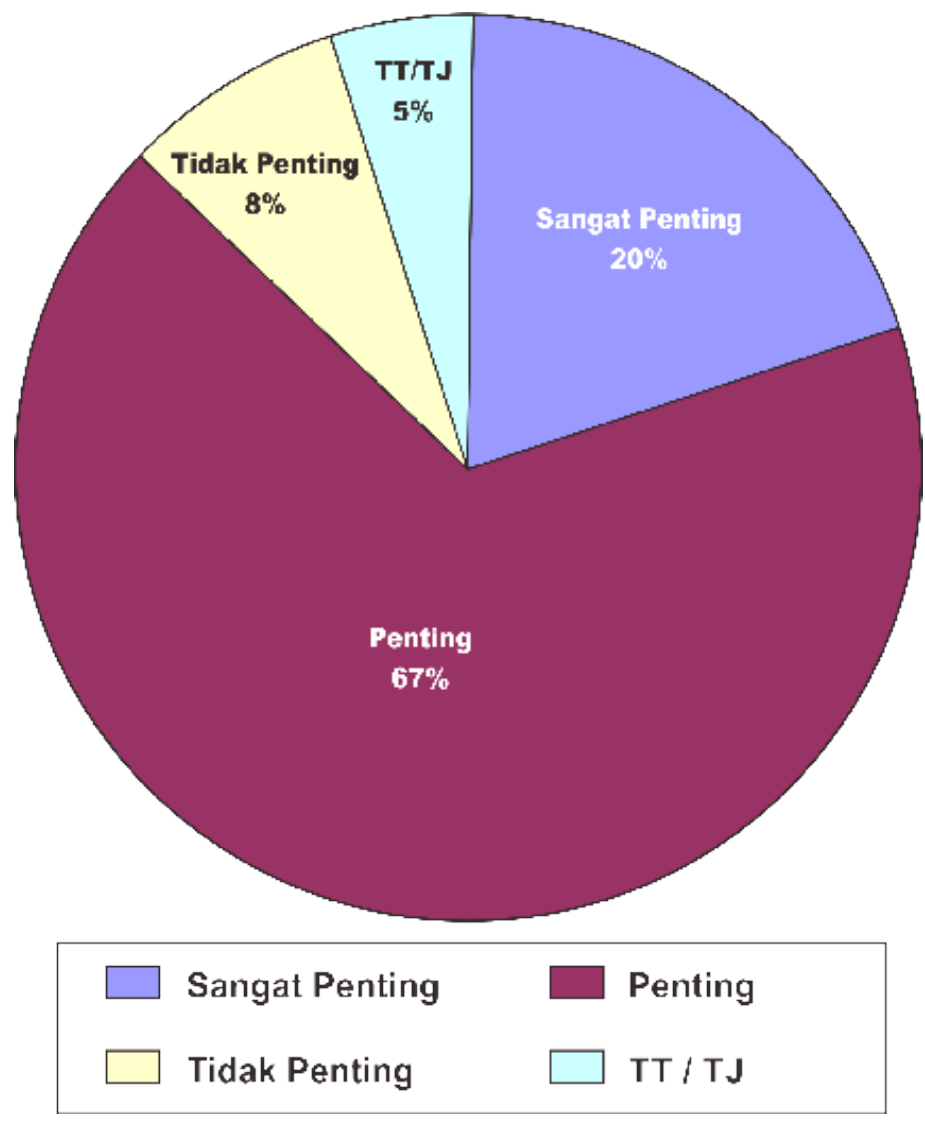

Sumber: LSI-IFES, 2014 
Sayangnya, ketika proses sosialisasi kepada target sasaran dan pelaksana lapangan dirasakan sangat kurang karena masih pada tingkat pusat saja sedangkan kepada penyandang disabilitas lainnya yang berada pada posisi masyarakat biasa artinya tidak pernah ikut terlibat aktif dalam kepemiluan menjadi kurang informasi dan pelaksana di lapangan yaitu KPPS juga tidak melaksanakan kebijakan yang dibuat.

Sehingga penting adanya pemahaman yang lebih baik yang dibangun baik dari tingkat penyelenggara maupun tokoh atau pemerhati atau penyandang disabilitas sekalipun dalam meningkatkan pemahaman terhadap pelaksana lapangan dan penyandang disabilitas itu sendiri agar lebih respon terhadap peningkatan aksebilitas dalam Pemilu terhadap penyandang disabilitas sehingga muncul keadilan dalam persamaan hak terutama hak politik atau memberikan suaranya dalam Pemilu menjadi terwujud kearah yang lebih baik. 


\section{Bibliografi}

Ariani, Konferensi Kesejahteraan Sosial, 2013.

Dahl, Robert A 1992, Demokrasi dan Para Pengkritiknya, Jakarta : Yayasan Obor Indonesia.

Hakim, G Abdul, Nusantara, 1996. Pemilu dalam Perspektif HAM, dalam Mendemokratiskan Pemilu, ELSAM : Jakarta.

JPPR, laporan pemantauan akses pemilu legislatif 2014 bagi penyandang disabilitas di dki jakarta, 2014.

PPUA PENCA, 2011, Buku Panduan Akses Pemilu : Jaminan Partisipasi Hak politik Bagi Penyandang Disabilitas, Jakarta.

PPUA PENCA, 2011, Buku Panduan Akses Pemilu : Jaminan Partisipasi Hak politik Bagi Penyandang Disabilitas, Jakarta.

Pusat Data Informasi Kementerian Sosial Republik Indonesia, 2012.

Survey LSI - IFES, Pendapat Masyarakat Indonesia Tahun 2013 : Survey Nasional Berkaitan dengan Pemilu 2014.

Zak (2013 : Juli 10), Penyandang Cacat Diabaikan Pada Pemilu, diakses pada tanggal 27 Februari 2014 di http://politik.pelitaonline.com. 